\title{
Management of Wage-To-Labor Productivity Correlation as a Factor of Samara Region Economic Development
}

\author{
I.V. Bogatyreva ${ }^{1, *}$, N.V. Kozhukhova ${ }^{1}$, and D.A. Acopyan ${ }^{1}$ \\ *Corresponding author: scorpiony70@mail.ru. \\ ${ }^{1}$ Samara State University of Economics, Samara, Russia
}

\begin{abstract}
The paper considers the problems in management of the wage-to-labor productivity correlation as the most important element in the strategic development of Samara region economy. The rational correlation between labor productivity and wages growth affects production cost reduction, and increases profitability and production efficiency. This explains the relevance of the study on the wage-to-labor productivity correlation in the digital economy. The authors present the results of the research on the dynamics of labor productivity and wages in Samara region in $2010-2017$. They calculated the correlation figures of average wages growth in Samara region economy, described the model and developed the mechanism to manage the wage-to-labor productivity correlation.
\end{abstract}

Keywords: labor productivity, own-product real wage, wages, lead factor of wages.

\section{Introduction}

The problem of the wage-to-labor productivity correlation is an important economic issue. Change regularities in labor productivity and wages reflect many aspects of industrial relations in any society. The economic meaning of the priority development in productivity, in comparison with wages, on the one hand, reduces the unit costs of wages for production turnout and increases the surplus product share, which is spent on the production expansion and social needs, and, on the other hand, strengthens the material base of wages growth.

The importance of the problem to regulate the wage-to-labor productivity correlation in the digital economy becomes essential for each enterprise, region and country. The possibility of expanded reproduction, balance in the consumer goods market and product coverage of growing cash income depends on the efficient solution of this problem. In this regard, the study is extremely relevant. It is particularly relevant for Russia due to a number of serious problems that the country has faced in recent decades: increasing pressure from foreign competitors, dependence on raw materials exports and world prices on them, low living standards, etc.

\section{Problem Statement}

For a long period of time, the scientific community and politicians of the leading world countries are interested in the problem of the wage-to-labor productivity correlation [1,2]. It has acquired particular relevance today in the context of the digital economy development. Economic progress in the modern world is based on labor productivity growth. It is labor productivity, more than any other factor, that determines the level and quality of life in the whole society, and is the best indicator of economic efficiency in the long term. The wage-to-labor productivity correlation reflects the ratio between production, distribution and consumption. Consequently, the value of product, produced by workers, must be greater than the value of products they consume. Without implementation of this principle, it is impossible to constantly expand and improve production. Objective economic laws show that there is a direct correlation between labor productivity and wages growth [3]. According to the results of some research studies, this correlation is bilateral [4].

In the economic and managerial literature, the issue of growth rate of labor productivity in excess of wages is widely discussed. It is impossible not to agree with the statement of some authors that labor productivity growth should be accompanied by a proportional increase in wages, because it affects increase in profits and economic efficiency [5]. However, in practice, the wage-to-labor productivity correlation often weakens due to the impact of external factors on the growth of these indicators [6]. Such factors may include inefficient utilization and distribution of labor and capital [7], form of ownership and size of exports [8]. Internal factors, such as rationalization of working time [9], implementation of digital technologies and efficient management of labor regulation, [10] also influence the optimal ratio of labor productivity and wages growth. Thus, the search for the optimal wage-to-labor productivity correlation is an important economic task.

\section{Research Questions}

The low level of labor productivity in enterprises affects the overall efficiency of the production system, because labor productivity is a criterion for efficiency of labor utilization in a production activity [11]. For this reason, for a long time, 
the subject of research of Russian and foreign scientists is productivity growth, payroll management as one of the effective tools to increase labor activity of workers to achieve the necessary level of their labor productivity, and rational wage-tolabor productivity correlation. However, discussions on these issues are still ongoing. Many scientists are interested in the following questions: is there a close wage-to-labor productivity correlation [12], what is the optimal ratio between labor productivity and wages, what model of wage-to-labor productivity correlation can be used for the further development of the Russian economy, what factors influence labor productivity and wages growth [13], and how to effectively manage the growth of labor productivity and wages with their ratio at the level of enterprise, region and country.

\section{Purpose of the Study}

The objectives of the study, the results of which are reflected in this paper, are to analyze and evaluate the wage-tolabor productivity correlation at the regional level and develop a mechanism to manage it. To achieve the objectives of this research, the following tasks were accomplished: the dynamics of labor productivity and wages in Samara region was analyzed, the correlation level between labor productivity and wages was assessed, the models of correlation between labor productivity and wages growth were described, and the mechanism to manage the wage-to-labor productivity correlation was elaborated.

\section{Research Methods}

The study is based on systematic and analytical methods of quantitative and qualitative analysis. Monitoring of data collection, study of statistical information on the dynamics of labor productivity and wages in the economy of Samara region allowed the authors to obtain reliable results of the research and formulate reasonable conclusions.

Analysis and evaluation of the wage-to-labor productivity correlation involves the study of the dynamics in the indicators under investigation, which is characterized by the rates of their growth and gain. To study the dynamics of wages and labor productivity in the economy of Samara region for a six-year period, the authors of the paper calculated the index for 2012-2017.

The calculated labor productivity rate is the volume of gross regional product per one employed in the economy of Samara region.

To examine in depth the wage-to-labor productivity correlation, the following indicators were calculated: ownproduct real wage, lead factor in nominal and real wages and increment rate of average wages for every one percent increase in productivity.

\section{Findings}

\subsection{Labor productivity and wages in Samara region economy}

The object of the study is Samara region, which belongs to one of the key industrial regions of the Russian Federation. Opportunities for productivity growth are determined by the developed regional production infrastructure, which is characterized by industry diversity, high level of labor potential, high opportunities for the development of transport communications and many other advantages in the regional economic and social life.

The study of trends in labor productivity and wages growth in Samara region economy over an eight-year period allows to identify the expansion and contraction in the dynamics of these key indicators. Our calculations showed that although during the period under review labor productivity in the region has a positive trend (growth to $23.3 \%$ ), in recent years there has been a decline in the growth rate of this index. This situation was affected by decrease in the growth rate of labor force in the region and gross value added in 2015-2016. In 2017, the situation changed to the better: productivity growth was $3.3 \%$ due to increase in gross product by $0.8 \%$ (Table 1 ).

Table 1. Labor productivity and wages in Samara region economy in 2010-2017, \%.

\begin{tabular}{|l|c|c|c|c|c|c|c|c|c|}
\hline \multicolumn{1}{|c|}{ Index } & 2010 & 2011 & 2012 & 2013 & 2014 & 2015 & 2016 & 2017 & $\begin{array}{c}2017 \text { to } \\
2010\end{array}$ \\
\hline Gross regional product & 108.5 & 105.9 & 105.0 & 104.2 & 101.9 & 97.0 & 97.8 & 100.8 & 122.5 \\
\hline Number of employed persons & 100.2 & 100.5 & 101.5 & 100.2 & 100.8 & 99.3 & 99.3 & 97.6 & 99.4 \\
\hline Labor productivity & 108.3 & 105.4 & 103.4 & 104.0 & 101.1 & 97.7 & 98.5 & 103.3 & 123.3 \\
\hline Average monthly nominal wages & 110.5 & 112.9 & 111.8 & 112.8 & 110.3 & 103.7 & 105.4 & 107.8 & 204.5 \\
\hline Real wages & 104.3 & 104.4 & 107.5 & 106.3 & 102.4 & 89.9 & 98.8 & 103.7 & 117.4 \\
\hline
\end{tabular}

Source: Authors. 
Wages are the main source of income for Russians. In recent years, its share in total cash income has been fluctuated at the level of $65-70 \%$. In Samara region, the population has a slightly different structure of monetary income: wages accounts for about $38.8 \%$ of all monetary income.

The analysis of the dynamics in nominal and real wages is of particular interest. The results of our research in Samara region indicate an annual growth of average monthly nominal wages by a mean of $9.4 \%$. The fluctuant trend is present in the dynamics of average real wages: it reached the highest growth in $2012(7.5 \%)$ and the negative growth in $2015-2016$ (10.1\% and 1.2\%, respectively). The reason for the heterogeneous dynamics in nominal and real wages lies in the decrease in the purchasing power of nominal wages: the prices of goods and services grow faster than its size.

\subsection{Growth rates in labor productivity and wages in Samara region economy}

Growth rates in labor productivity and wages require a special attention on the part of employers and the state. According to statistics, over a long period of time, wages growth has significantly surpassed labor productivity growth both in the whole country and in particular regions. Our calculations show that the same situation is observed in Samara region. In 2010-2017 in the region, with labor productivity growth by $23.3 \%$, average gross nominal wages increased by 2 times, and average real wages increased almost by 1.2 times (Fig. 1).

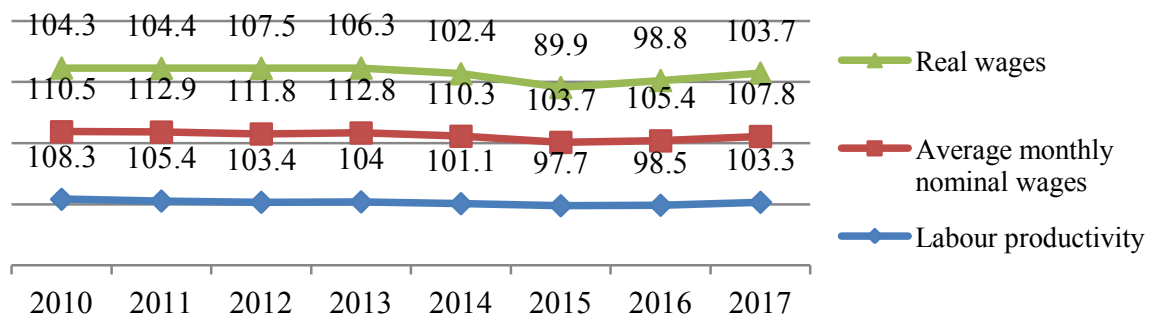

Fig. 1. Dynamics of labor productivity and wages in the Samara region economy in 2010-2017. Source: Authors

Consequently, the lead factor of nominal wages (60.4\%) is firmly low and own-product real wage is high (165.7\%) (Table 2).

Table 2. Calculation of index of wage-to-labor productivity in Samara region economy in 2010-2017, \%

Source: Authors.

\begin{tabular}{|l|c|c|c|c|c|c|c|c|c|}
\hline \multicolumn{1}{|c|}{ Index } & 2010 & 2011 & 2012 & 2013 & 2014 & 2015 & 2016 & 2017 & $\begin{array}{c}2017 \text { to } \\
2010\end{array}$ \\
\hline Lead factor: & & & & & & & & & \\
- nominal wages & 98.0 & 93.4 & 92.5 & 92.2 & 91.7 & 94.2 & 93.5 & 95.8 & 60.4 \\
- real wages & 103.8 & 100.9 & 96.2 & 97.8 & 98.7 & 108.7 & 99.7 & 99.6 & 104.9 \\
\hline $\begin{array}{l}\text { One-product real wage: } \\
\text { - nominal }\end{array}$ & 102.0 & 107.1 & 108.1 & 108.5 & 109.1 & 106.1 & 107.0 & 104.4 & 165.7 \\
- real & 96.3 & 99.1 & 103.9 & 102.2 & 101.3 & 92.0 & 100.3 & 100.4 & 95.1 \\
\hline
\end{tabular}

The analysis of index of the wage-to-labor productivity correlation showed that the change in the unit costs of nominal wages per unit of production output, throughout the period under review, remains quite high (from $102 \%$ in 2010 to $104.4 \%$ in 2017). Consequentially, it affects the cost of production.

The ratio of the growth rate of average wages is characterized by another indicator. It is the increment rate of average wages growth for each percentage of labor productivity growth (Table 3).

Table 3. Calculation of the increment rate of average wages for each percentage of labor productivity growth in Samara region, \%

\begin{tabular}{|c|c|c|c|c|c|c|}
\hline Index & 2010 & 2011 & 2012 & 2013 & 2014 & 2017 \\
\hline Average nominal wages growth & 10.5 & 12.9 & 11.8 & 12.8 & 10.3 & 7.8 \\
\hline Average real wages growth & 4.3 & 4.4 & 7.5 & 6.3 & 2.4 & 3.7 \\
\hline Labor productivity growth & 8.3 & 5.4 & 3.4 & 4 & 1.1 & 3.3 \\
\hline $\begin{array}{l}\text { Increment rate of average wages for each percentage of } \\
\text { labor productivity growth }\end{array}$ & 1.26 & 2.39 & 3.5 & 3.2 & 9.36 & 2.36 \\
\hline $\begin{array}{l}\text { Increment rate of average real wages for each percentage } \\
\text { of labor productivity growth }\end{array}$ & 0.5 & 0.8 & 2.2 & 1.58 & 2.2 & 1.1 \\
\hline
\end{tabular}

Source: Authors.

The results of the study show that from 2010 to 2014 there was an increase in growth of nominal and real wages for each percentage of labor productivity growth (7.5 and 4.4 times, respectively). In 2017 , the situation changed. There was a decrease in growth of both nominal and real wages for each percentage of labor productivity growth. This is due to a decrease in the level of population's income including wages because of the United States and the European Union 
sanctions. High rates of wages growth have a positive impact on Samara region economy and contribute to improve the living standards. However, in the absence of a corresponding increase in labor productivity, the positive dynamics in wages increase comes to nothing. The increase in one-product real wage leads to increase in prices for goods and services, and the strengthening of inflationary development. This affects the economic and political climate of particular regions and the country [14].

At the legislative level, the government of the Russian Federation take steps to solve the problems to accelerate labor productivity growth in the country. Since 2017 the National Program to improve labor productivity: Priority Program Passport "Improving labor productivity and support for employment" in key regions, including Samara region, has been carrying out.

\subsection{Models and mechanism to manage the wage-to-labor productivity correlation}

In world practice, three models of correlation between labor productivity and wages growth gained popularity:

- classical model includes providing of direct proportional dependence between wages and labor productivity: an increase in labor productivity by $10 \%$ leads to increase in wages by $10 \%$,

- inflation model is based on faster wage growth in comparison with labor productivity growth: wages are growing at a faster rate than labor productivity,

- stimulating model is based on the lag of wages growth behind labor productivity growth.

The classical model of the wage-to-labor productivity correlation is the most suitable for the economic development, but in practice, it is extremely rare. According to the results of our study, the Russian economy is based on the inflationary model of the wage-to-labor productivity correlation. It has negative consequences: lack of correlation between labor costs and payment, discouragement of labor productivity increase, reduction of wages purchasing power, etc.

The authors developed the mechanism to manage the wage-to-labor productivity correlation, which includes 4 stages (Fig. 2).

\section{Conclusion}

Today, ensuring the optimal wage-to-labor productivity correlation is one of the primary tasks of the Russian economy. The main directions to increase the growth level of labor productivity and achieve the optimal correlation between the labor productivity and wages growth in Samara region are: reducing the cost of financial resources, improving product competitiveness, reducing the credit and tax burden, increasing the innovation level and demand by stimulating consumers' purchasing power, strengthening workers' labor activity, increasing minimum earnings to the level of minimum restorative consumer budget [15], and implementation of scientifically grounded payroll management in enterprises.

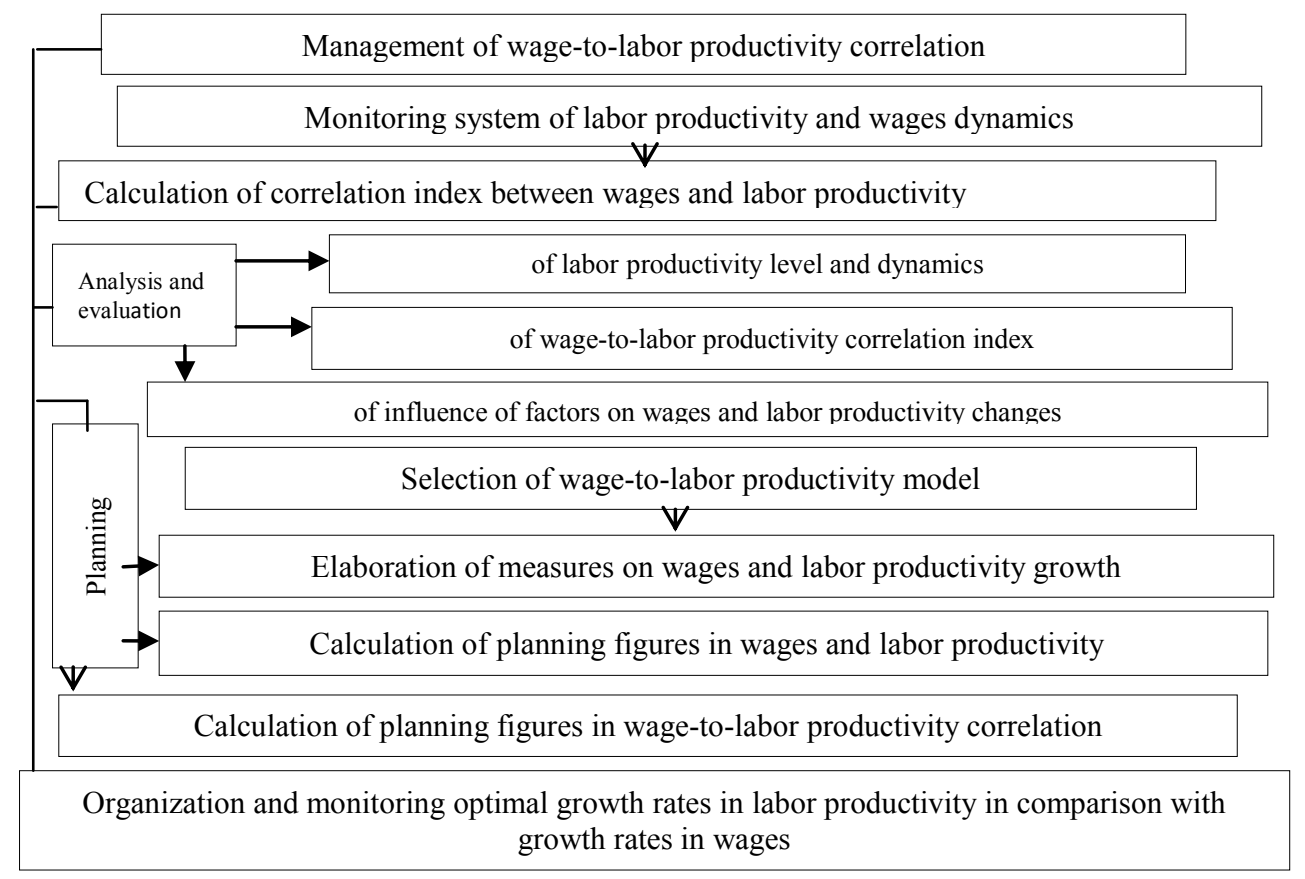

Fig. 2. Mechanism to manage the wage-to-labor productivity correlation. Source: Authors. 


\section{References}

1. J. Pehkonen, Wages and productivity growth in the Nordic countries. European Economic Review, 39(6), 1181-1196 (1995). DOI: 10.1016/0014-2921(94)00017-T.

2. H. Bester, E. Petrakis, Wages and productivity growth in a dynamic monopoly. International Journal of Industrial Organization, 22(1), 83-100 (2004). DOI: 10.1016/S0167-7187(03)00093-6.

3. R. Riley, C. Rosazza Bondibene, Raising the standard: Minimum wages and firm productivity. Labor Economics, 44, 27-50 (2017). DOI: 10.1016/j.labeco.2016.11.010.

4. M. Millea, S.M. Fues Jr., Does pay affect productivity or react to it? Examination of U.S. manufacturing. The Quarterly Review of Economics and Finance, 45(4-5), 796-807 (2005). DOI: 10.1016/j.qref.2004.06.004.

5. A.V. Kovalenko, E.S. Kalinskaya, I.V. Geleta, Areas of productivity growth. Sustainable Development Economics, 3(19), 99-104 (2014). [in Rus.].

6. M. Fafchamps, S. El Hamine, Firm productivity, wages, and agglomeration externalities. Research in Economics, 71(2), 291-305 (2017). DOI: 10.1016/j.rie.2016.12.003.

7. K. Nakamura, S. Kaihatsu, T. Yagi, Productivity improvement and economic growth: Lessons from Japan. Economic Analysis and Policy, 62, 57-79 (2019). DOI: 10.1016/j.eap.2018.11.002.

8. J. Zhang, X. Liu, The evolving pattern of the wage - labor productivity nexus in China: Evidence from manufacturing firm-level data. Economic Systems, 37(3), 354-368 (2013). DOI: 10.1016/j.ecosys.2013.05.001.

9. I.V. Bogatyreva, L.A. Ilyukhina, M.V. Simonova, N.V. Kozhukhova, Estimation of the efficiency of working time usage as a factor of sustainable increase of labor productivity. In: V. Mantulenko (Ed.), Proceedings of the 17th International Scientific Conference "Problems of Enterprise Development: Theory and Practice", SHS Web of Conferences, 62 (06002). Les Ulis: EDP Sciences (2019).

10. V.A. Schekoldin, I.V. Bogatyreva, L.A. Ilyukhina, V.M. Kornev, The development of IT-technologies in labor standardization and quality assessment of standards: Challenges and ways of solution in Russia. Helix, 8(5), 36153628 (2018). DOI: 10.29042/2018-3615-3628.

11. I. Bogatyreva, M. Simonova, E. Privorotskaya, Current state of labor productivity in the economy of developed countries. In A. Zheltenkov (Ed.), Proceedings of Topical Problems of Architecture, Civil Engineering and Environmental Economics (TPACEE 2018), E3S Web of Conferences, 91(08022). Les Ulis: EDP Sciences (2019).

12. A.A. Popkov, About the relationship of labor productivity growth and wage growth. Modern Science, 4, 61-64 (2015). [in Rus.].

13. V.V. Aranzhin, The relationship of wages and productivity: Trends in the conditions of economy digitization. Russian Journal of Labor Economics, 6(1), 523-534 (2019). [in Rus.].

14. I.V. Bogatyreva, N.V. Kozhukhova, E.P. Zheleznikova, Analysis of the current state of labor productivity in Russia. Russian Journal of Labor Economics, 5(3), 683-698 (2018). [in Rus.].

15. V.A. Vaisburd, M.V. Simonova, I.V. Bogatyreva, E.G. Vanina, E.P. Zheleznikova, Productivity of labor and salaries in Russia: Problems and solutions. International Journal of Economics and Financial Issues, 6(S5), 157-165 (2016). 